\title{
Acaricidal activity of Annonaceae fractions against Tetranychus tumidus and Tetranychus urticae (Acari: Tetranychidae) and the metabolite profile of Duguetia lanceolata (Annonaceae) using GC-MS
}

\author{
Atividade acaricida de frações de anonáceas para Tetranychus \\ tumidus e Tetranychus urticae (Acari: Tetranychidae) e perfil \\ metabólito de Duguetia lanceolata (Annonaceae) por CG-EM
}

\author{
Dejane Santos Alves ${ }^{1 *}$; Reinaldo Chico Morejón ${ }^{2}$; Alan Rodrigues Teixeira Machado 3 ; \\ Geraldo Andrade Carvalho, ${ }^{4}$ Oriela Pina ${ }^{5}$; Denilson Ferreira Oliveira ${ }^{6}$
}

\begin{abstract}
Species of the Tetranychus genus feed on plant tissues, which reduces the rate of photosynthesis and can lead to the death of plant tissues. As a result, considerable production losses are caused by these arthropods. Thus, in order to aid in the development of new products for the control of Tetranychus tumidus Banks and Tetranychus urticae Koch (Acari: Tetranychidae), the initial objective of this study was to select Annonaceae derived fractions that were soluble in dichloromethane and have acaricidal activity. Then, an exploratory analysis of the metabolite profile of the most successful fraction was performed by gas chromatography-mass spectrometry (GC-MS). Among the dichloromethane soluble fractions derived from Annona cacans Warm., Annona coriacea Mart., Annona neolaurifolia H. Rainer, Annona sylvatica A.St.-Hil., Duguetia lanceolata A.St.-Hil., Guatteria australis A.St.-Hil., Xylopia brasiliensis Spreng., Xylopia emarginata Mart. and Xylopia sericea A.St.-Hil., only the fraction from $D$. lanceolata stem bark reduced the survival of T. tumidus females. However, ovicidal activity was not detected when $D$. lanceolata stem bark was evaluated against $T$. tumidus eggs. Further, we studied the effect of dichloromethane soluble fractions from $D$. lanceolata leaves, berry fruits and stem bark on $T$. urticae, and the stem bark was found to be the most active fraction against T. urticae. The metabolite profile analysis of $D$. lanceolata stem bark by GC-MS, suggested that the main constituents were 2,4,5-trimethoxystyrene and trans-asarone.
\end{abstract}

Key words: Botanic acaricide, secondary metabolites, 1,2,4-trimethoxy-5-vinylbenzene, 1,2,4-trimethoxy-5-[(1E)-1-propen-1-yl]benzene

\section{Resumo}

As espécies do gênero Tetranychus alimentam-se de tecidos vegetais acarretando redução na capacidade fotossintética da planta, que pode resultar em morte dos tecidos vegetais, como consequência são

\footnotetext{
${ }^{1}$ Bolsista de Pós-Doutorado Júnior PNPD/CNPq/UFLA. Departamento de Entomologia, Universidade Federal de Lavras, UFLA, Lavras, MG, Brasil. E-mail: dejane_bio@yahoo.com.br

2 Técnico de Laboratório, CENSA, Centro Nacional de Sanidad Agropecuáaria, San José de las Lajas, Cuba. E-mail: chico@ censa.edu.cu

${ }^{3}$ Bolsista de Pós-Doutorado Júnior PMPD/CAPES \& FAPEMIG/UFMG, Dept ${ }^{\circ}$ de Química, Universidade Federal de Minas Gerais, UFMG, Belo Horizonte, MG, Brasil. E-mail: alanvisconde@gmail.com

${ }^{4}$ Prof. Titular, Dept ${ }^{\circ}$ de Entomologia, UFLA, Lavras, MG, Brasil. E-mail: gacarval@den.ufla.br

5 Pesquisadora, CENSA, Centro Nacional de Sanidad Agropecuaria, San José de las Lajas, Cuba. E-mail: oriela@censa.edu.cu

${ }^{6}$ Prof. Adjunto, Dept ${ }^{\circ}$ de Química, UFLA, Lavras, MG, Brasil. E-mail: denilson@dqi.ufla.br

* Author for correspondence
} 
consideráveis as perdas na produção causadas por esses artrópodes. Assim, com vistas a contribuir para o desenvolvimento de novos produtos para o controle dos ácaros Tetranychus tumidus Banks e Tetranychus urticae Koch (Acari: Tetranychidae) o objetivo inicial deste trabalho foi selecionar frações solúveis em diclorometano com atividade acaricida, provenientes de extratos metanólicos de espécies de anonáceas. Em seguida, buscou-se realizar análise exploratória do perfil metabólito da fração selecionada por meio da cromatografia gasosa acoplada a espectrometria de massas (CG-EM). Dentre as frações solúveis em diclorometano oriundas de Annona cacans Warm., Annona coriacea Mart., Annona neolaurifolia H. Rainer, Annona sylvatica A.St.-Hil., Duguetia lanceolata A. St.-Hil., Guatteria australis A.St.-Hil., Xylopia brasiliensis Spreng., Xypolia emarginata Mart. e Xylopia sericea A.St.-Hil., apenas aquela proveniente das cascas do caule de $D$. lanceolata causou redução na sobrevivência de fêmeas de $T$. tumidus. Entretanto, quando avaliado o efeito da fração das cascas do caule de D. lanceolata sobre ovos de T. tumidus não foi constatada atividade ovicida. Quanto a T. urticae, foi estudado o efeito das frações solúveis em diclorometano provenientes das folhas, frutos e cascas do caule de $D$. lanceolata, sendo que a mais ativa contra o ácaro foi a proveniente das cascas do caule. A análise do perfil metabólito da fração das cascas do caule de $D$. lanceolata, por meio de CG-MS, sugeriu que os constituintes majoritários são o 2,4,5-trimetoxiestireno e a trans-asarona.

Palavras-chave: Acaricida botânico, metabólitos secundários, 1,2,4-trimetoxi-5-vinilbenzeno, 1,2,4-trimetoxi-5-[(E)-prop-1-enil]benzeno

\section{Introduction}

The Tetranychidae family includes the main group of phytophagous mites. Several species of this family are pests in many cropping systems (MARCIC, 2012). Among the species of phytophagous mites that cause agricultural losses, Tetranychus tumidus Banks (Acari: Tetranychidae) is the key pest in plantain (Musa spp.) nurseries in Cuba, whereas Tetranychus urticae Koch (Acari: Tetranychidae) is an important pest of many horticultural crops in both Brazil and Cuba. Synthetic acaricides have been used as the main mite control strategy. However, the indiscriminate use of these pesticides, coupled with the high reproductive potential and short life cycle of the mites, has led to the development of resistant populations in different places (SATO et al., 2005; LEEUWEN et al., 2010; SOKOLYANSKAYA, 2010).

In this context, the use of derivatives from plant metabolism to control mites has been the subject of an increasing number of studies (YANAR et al., 2011; ERDOGAN et al., 2012; VERONEZ et al., 2012). Acaricidal activity was previously reported in an extract of the roots of Phytolacca americana L. (Phytolaccaceae) (DING et al., 2013). Similarly, leaf extracts from Anisosciadium orientale DC.
(Apiaceae), Scaligeria meifolia Boiss. (Apiaceae), Trigonella elliptica Boiss. (Fabaceae), and Dodonaea viscosa L. (Sapindaceae) showed promising acaricidal activity (GHADERI et al., 2013). It is also possible that Deverra scoparia Coss. \& Durieu (Apiaceae), Haplophyllum tuberculatum (Forsskal) A. Juss. (Rutaceae), Chrysanthemum coronarium L. (Asteraceae), and Mentha pulegium L. (Lamiaceae) extracts have acaricidal activity (ATTIA et al., 2012).

It has been shown that plant metabolites can have repellent effects, contact toxicity, inhibit enzymatic processes, and change reproductive variables, which kill or reduce the reproductive performance of mites (LÜMMEN, 1998; LABORDA et al., 2013; ZHANG et al., 2013). Numerous plant families are known to produce metabolites that are toxic to these phytophagous mites, among which, the Annonaceae family deserves special attention, because there have been many intensive studies that have evaluated this family's use as a pesticide producers (MCLAUGHLIN, 2008; GUPTA et al., 2011; MADHUMITHA et al., 2012). This study aimed to evaluate the bioactivity of dichloromethane soluble fractions from methanol extracts of plants from the Annonaceae family, originating from the Alto do Rio Grande region in Minas Gerais, Brazil, 
against a Cuban population of T. tumidus. Duguetia lanceolata fractions, the most active plant fractions against T. tumidus, were tested to see if they could control T. urticae. We also analyzed the metabolic profile of $D$. lanceolata by gas chromatographymass spectrometry (GC-MS).

\section{Materials and Methods}

\section{Collection and processing of plant materials}

The botanical materials used to perform the bioassays were collected from the Alto Rio Grande region-Lavras/Minas Gerais, between March and April 2011. Samples of the materials were also used for making voucher specimens, which were deposited in the ESAL (Escola Superior de Agricultura de Lavras) herbarium (Table 1). The leaves, stem bark, and berry fruits were initially dried in an oven with forced ventilation at $40^{\circ} \mathrm{C}$ for 48,72 , or $96 \mathrm{~h}$. Then the samples were ground in a Willey mill, which produced the ground materials that were used in the preparation of the extracts and fractions.

Table 1. Botanical materials used in the preparation of dichloromethane soluble fractions derived from plant extracts.

\begin{tabular}{lccc}
\hline Scientific name & Synonymies $^{1}$ & $\begin{array}{c}\text { Collected } \\
\text { part }\end{array}$ & $\begin{array}{c}\text { Continue ... } \\
\text { specimen number }\end{array}$ \\
\hline Annona cacans Warm. & - & Leaves & 27639 \\
\hline Annona coriacea Mart. & - & Leaves & 27640 \\
\hline Annona neolaurifolia & Rollinia laurifolia Schltd & Leaves & 27638 \\
H. Rainer & Stem bark & 276 \\
\hline
\end{tabular}

Annona silvestris Vell., Annona fagifolia A.St.-Hil. \& Annona sylvatica A.St.- Tul., Annona exalbida Vell., Rollinia sylvatica (A.St.Hil. $\quad$ Hil.) Mart., Rollinia exalbida (Vell.) Mart., Rollinia Leaves $\quad 27647$ fagifolia A.St.-Hil.

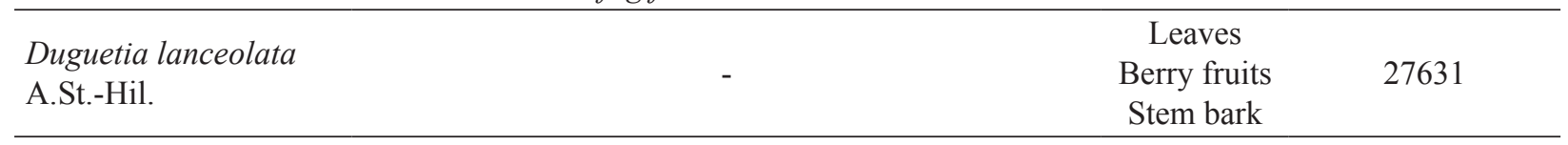

Guatteria acutiflora Mart., Guatteria acutipetala R.E.Fr., Guatteria asterantha R.E.Fr., Guatteria blanchetiana R.E.Fr., Guatteria clavigera R.E.Fr., Guatteria curvinervia R.E.Fr., Guatteria densicoma Mart., Guatteria dimorphopetala R.E.Fr., Guatteria dusenii R.E.Fr., Guatteria flava A.St.-Hil., Guatteria fruticosa R.E.Fr., Guatteria glabrescens R.E.Fr., Guatteria gomeziana A.St.-Hil., Guatteria hilariana

Guatteria australis A.St.-Hil.
Schltdl., Guatteria hookeri A.St.-Hil. \& Tul., Guatteria klotzschiana Mart., Guatteria lutea A.St.-Hil., Leaves 27645

Guatteria minarum R.E.Fr., Guatteria mosenii R.E.Fr., Guatteria neglecta R.E.Fr., Guatteria nigrescens Mart., Guatteria odontopetala Mart., Guatteria paranensis

R.E.Fr., Guatteria parvifolia R.E.Fr., Guatteria penduliflora R.E.Fr., Guatteria polycarpa R.E.Fr., Guatteria psilopus Mart., Guatteria reflexa R.E.Fr., Guatteria riedeliana R.E.Fr., Guatteria salicifolia R.E.Fr., Guatteria silvatica R.E.Fr., Guatteria sordida R.E.Fr., Guatteria tenuis R.E.Fr. 


\begin{tabular}{lccc}
\hline $\begin{array}{l}\text { Xylopia brasiliensis } \\
\text { Spreng. }\end{array}$ & Xylopia gracilis R.E.Fr. & Leaves & 27636 \\
\hline $\begin{array}{l}\text { Xylopia emarginata } \\
\text { Mart. }\end{array}$ & - & Stem bark & Leaves \\
\hline $\begin{array}{l}\text { Xylopia sericea } \text { A.St.- } \\
\text { Hil. }\end{array}$ & Xylopia intermedia R.E.Fr. & $\begin{array}{c}\text { Stem bark } \\
\text { Leaves }\end{array}$ & 27646 \\
\hline
\end{tabular}

${ }^{1}$ Oliveira-Filho (2013).

Preparation of plant extracts and liquid-liquid partitioning

The dried and ground plant material (50 g) was immersed in methanol $(300 \mathrm{~mL})$ for $24 \mathrm{~h}$. Then the mixtures were filtered through hydrophilic cotton and $200 \mathrm{~mL}$ methanol was added to the residue. The extraction procedure was repeated eight times. The liquid phases were combined and the solvent removed in a rotary evaporator, which resulted in the dried methanolic plant extracts. The methanolic plant extracts $(5 \mathrm{~g})$ were suspended in water (20 $\mathrm{mL}$ ) so that they could be liquid-liquid partitioned with dichloromethane $(3 \times 20 \mathrm{~mL})$. The watersoluble phase was discarded in each extract, and the phases that were soluble in dichloromethane were combined, resulting in a solution that was then treated with anhydrous $\mathrm{Na}_{2} \mathrm{SO}_{4}$ to remove any humidity. The mixture was filtered through cotton, and concentrated and dried in a rotary evaporator. The final residue was lyophilized to produce the final dichloromethane soluble fraction (ÁLVAREZCOLOM et al., 2007, 2008, 2009). The different fractions were transported from Brazil to Cuba, which required a Plant Import Permit. This was issued by IBAMA-Instituto Brasileiro de Meio Ambiente (license number: 12BR008914/DF).

\section{Rearing and maintenance of the mites}

The mites used in the bioassays were obtained from the Acarology Laboratory at CENSA (Centro Nacional de Sanidad Agropecuaria, San José de las Lajas, Cuba), where specimens of T. tumidus were maintained on plantain leaves (Musa sp. var. Ciento en boca). The T. urticae were maintained on citrus leaves (Citrus latifolia). Adult females, aged between 48 and $72 \mathrm{~h}$, were used to conduct the bioassays.

Effects of dichloromethane soluble fractions on $\underline{T}$. tumidus adult females

The dichloromethane soluble fractions were obtained from methanolic extracts derived from the leaves of Annona cacans Warm., Annona coriacea Mart., Annona sylvatica A.St.-Hil., Guatteria australis A.St.-Hil., and Xylopia brasiliensis Spreng.; the leaves and stem bark of Annona neolaurifolia H. Rainere and Xylopia emarginata Mart.; and the leaves, stem bark, and berry fruits of Duguetia lanceolata A.St.-Hil. and Xylopia sericea A.St.-Hil. These fractions $(10 \mathrm{mg})$ were mixed with DMSO $(50 \mu \mathrm{L})$, and then an aqueous solution of Tween $80\left(0.01 \mathrm{v} \mathrm{v}^{-1}\right)(950 \mu \mathrm{L})$ was added, which resulted in a sample with a final volume of $1.0 \mathrm{~mL}$ and a concentration of $10 \mathrm{mg} \mathrm{mL}^{-1}$.

A microimmersion bioassay, adapted from Dennehy et al. (1993), was used for the topical application of dichloromethane soluble fractions to T. tumidus females. Plastic pipette tips $(200 \mu \mathrm{L})$ were cut in half and reconnected, so that a piece of organza fabric could be inserted to separate the internal space of the tip into two parts. A hose was attached to the thicker end of the tip, and at least 
25 adult females were suctioned up. Then, the tip was connected to a micropipette and $100 \mu \mathrm{L}$ of the fraction solution in DMSO and Tween 80 were sucked onto the tip. The mites remained immersed for $30 \mathrm{~s}$ and afterward were transferred to filter paper $(2 \mathrm{~cm} \times 2 \mathrm{~cm})$ to remove the treatments that had previously been in contact with the mites. Then, the mites were transferred to pieces of plantain leaves (approximately $5 \mathrm{~cm} \times 3 \mathrm{~cm}$ ) that were surrounded by cotton moistened with water. These inoculated leaves were then placed inside a Petri dish, which corresponds to an experimental plot.

The experiment had a completely randomized design with four replications per treatment. An experimental plot consisted of at least 25 adult females. Water and an aqueous solution containing DMSO $\left(0.05 \mathrm{v} \mathrm{v}^{-1}\right)$ and Tween $80\left(0.01 \mathrm{v} \mathrm{v}^{-1}\right)$ were used as negative controls. The positive control was the acaricide, dicofol $\left(0.01 \mathrm{v} \mathrm{v}^{-1}\right)$ (Dicofol 18,5 CE). The evaluations were performed 24,48 , and $72 \mathrm{~h}$ after the beginning of the experiment by counting the number of live and dead mites.

\section{Effect of the dichloromethane soluble fraction from D. lanceolata stem bark on T. tumidus eggs}

The treatments used were water; DMSO $(0.05 \mathrm{v}$ $\left.\mathrm{v}^{-1}\right)+$ Tween $80\left(0.01 \mathrm{v} \mathrm{v}^{-1}\right)$; soluble fraction from D. lanceolata stem bark $\left(10 \mathrm{mg} \mathrm{mL}^{-1}\right)$, and dicofol $\left(0.01 \mathrm{v} \mathrm{v}^{-1}\right)$ (Dicofol 18,5 CE). Plantain leaf pieces $(3.0 \times 3.0 \mathrm{~cm})$, with the edges wrapped in cotton moistened with distilled water, were placed in Petri dishes. A total of 100 females, aged between 24 and $48 \mathrm{~h}$, were transferred to each piece of leaf. They were kept there for $24 \mathrm{~h}$ so that they could lay eggs. The females were then removed and the eggs were counted. Excess eggs were removed with a paintbrush, which left approximately 50 eggs on each piece of leaf. The leaf pieces containing the eggs were immersed in $4 \mathrm{~mL}$ of each treatment for 30 seconds. Then the leaves were maintained for approximately $2 \mathrm{~h}$ at room conditions to allow them to dry out and then were arranged in Petri dishes (one piece of leaf per dish). The nymphs were counted after six days of treatment.

The experimental design was completely randomized and each experimental plot corresponded to a Petri dish with a piece of leaf containing about 50 eggs. Four replications were used per treatment, and the experiment was repeated twice.

Effect of the $\underline{D}$. lanceolata stem bark fraction on $\underline{T}$. urticae adult females

This bioassay used T. urticae females that had been kept in the laboratory. The method used was the adapted microimmersion bioassay, described above. The treatments were the fractions from the leaves, stem barks and berry fruits of $D$. lanceolata (10 $\left.\mathrm{mg} \mathrm{mL}^{-1}\right)$. The negative controls were water and DMSO $\left(0.05 \mathrm{v} \mathrm{v}^{-1}\right)+$ Tween $80\left(0.01 \mathrm{v} \mathrm{v}^{-1}\right)$ and the positive control was dicofol $\left(0.01 \mathrm{v} \mathrm{v}^{-1}\right)$ (Dicofol 18,5 CE). The experimental plot was a Petri dish containing a piece of citrus leaf and 25 females. The experimental design was completely randomized, and the evaluations were performed 24,48 , and 72 $\mathrm{h}$ after the experiment had begun by counting the number of live and dead mites. The experiment was repeated twice. In the first experiment, five replicates were used, whereas the second experiment only contained four replicates per treatment.

\section{Analysis by GC-MS}

The GC-MS analyses were performed on a gas chromatograph coupled to a mass spectrometer (Shimadzu GCMS-QP2010 Plus), equipped with an AOC-10 automatic injection system. Analyses were conducted using an Rxi1 capillary column $(30 \mathrm{~m} \times 0.25 \mathrm{~mm})$, coated with $100 \%$ polydimethylsiloxane. The thickness of the film was $0.25 \mu \mathrm{m}$, and helium was used as the carrier gas (flow rate of $7.2 \mathrm{~mL} \cdot \mathrm{min}^{-1}$ ). The injector temperature was $250^{\circ} \mathrm{C}$, while the 
column temperature ranged from $150^{\circ} \mathrm{C}$ to $280^{\circ} \mathrm{C}$ at a rate of $3^{\circ} \mathrm{C} \cdot \mathrm{min}^{-1}$. The injection volume was $1 \mu \mathrm{L}$ in split mode at a rate of 10:1. MS analysis was performed using a quadrupole system (QP2010plus) with electron impact ionization at $70 \mathrm{eV}$ under the same conditions as described above. The structures of the major compounds were suggested by comparing them to the structures found in the NIST 08 mass spectra libraries and in the literature.

\section{Statistical analysis}

In order to verify that the data was normal, the collected data were subjected to the ShapiroWilk test, using the mvnormtest package (JAREK, 2009). Analysis of variance was undertaken, and the means were compared by the Scott-Knott test, using the Laércio statistical package (SILVA, 2010). For the experiments that were repeated, joint analysis of data was conducted and the Bartlett test was used to verify the homogeneity of variances (R DEVELOPMENT CORE TEAM, 2013). R software, version 3.01 (R DEVELOPMENT CORE TEAM, 2013) was used to perform the analyses.

\section{Results and Discussion}

Effects of dichloromethane soluble fractions on $\underline{T}$. tumidus adult females

Only the dichloromethane soluble fraction of $D$. lanceolata stem bark reduced the survival of T. tumidus females after $24 \mathrm{~h}$ of immersion. In the evaluations performed after $48 \mathrm{~h}$ and $72 \mathrm{~h}$, it was observed that the fractions originating from the $D$. lanceolata stem bark and $X$. sericea berry fruits resulted in a lower average T. tumidus survival, when compared to the negative controls $(\mathrm{F}=123.34$; $\mathrm{df}=$ 17; $\mathrm{p} \leq 0.01$ ) (Table 2).

The D. lanceolata stem bark fraction was the most active against $T$. tumidus females. However, the fractions from leaves and fruit extracts were not bioactive. This result was possibly due to differences in intra-plant metabolite allocations (SOMKUWAR; KAMBLE, 2013; UDDIN et al., 2013). The stem bark results are the first report of acaricidal activity by $D$. lanceolata extracts. Although studies using Duguetia spp. are scarce, it is noteworthy that the Duguetia furfuracea (St. Hil) Bent. extract was not active against Rhipicephalus microplus Canestrini (Acari: Ixodidae) (VALENTE et al., 2014). This study seems to confirm the results from previous phytochemical studies with $D$. lanceolata, which also detected chemical groups that possessed acaricidal activity (NEVES; DA CAMARA, 2011), such as isoquinoline alkaloids (FISCHER et al., 2004; TEMPONE et al., 2005) and sesquiterpenes (SOUSA et al., 2012).

Previous studies have suggested that Annona spp. has acaricidal activity against Tetranychus spp. (POTENZA et al., 2006; LIN et al., 2009), which in part may be due to the production of acetogenins by this species, which are known to have acaricidal activity (LÜMMEN, 1998). Although there are no previous reports of $A$. cacans acaricide activity against Tetranychus spp., alkaloids have been isolated from this plant, such as liriodenine (SAITO; ALVARENGA, 1994), for which an acaricidal activity against Dermatophagoides pteronyssinus (Trouessart) (Acari: Pyroglyphidae) has already been reported (AKENDENGUE et al., 2003). However, in this study, the Annona genus species were not active against T. tumidus. 
Table 2. Survival (\%) (mean \pm SEM) of Tetranychus tumidus females subjected to treatment with soluble dichloromethane fractions from Annonaceae methanolic extracts, using an adapted micro-immersion bioassay technique, after 24,48 , and $72 \mathrm{~h}$.

\begin{tabular}{|c|c|c|c|c|}
\hline Treatments & $\mathbf{n}^{1}$ & $24 h^{2}$ & $48 h^{2}$ & $72 \mathrm{~h}^{2}$ \\
\hline Water & 148 & $93.6 \pm 2.96 \mathrm{aA}$ & $92.7 \pm 2.40 \mathrm{aA}$ & $91.8 \pm 2.10 \mathrm{aA}$ \\
\hline DMSO $\left(0.05 \mathrm{v}^{\cdot} \mathrm{v}^{-1}\right)+$ Tween $80\left(0.01 \mathrm{v} \cdot \mathrm{v}^{-1}\right)$ & 139 & $94.0 \pm 2.15 \mathrm{aA}$ & $94.0 \pm 2.15 \mathrm{aA}$ & $94.0 \pm 2.15 \mathrm{aA}$ \\
\hline Annona cacans leaves & 177 & $97.2 \pm 1.05 \mathrm{aA}$ & $97.2 \pm 1.05 \mathrm{aA}$ & $96.0 \pm 1.11 \mathrm{aA}$ \\
\hline Annona coriacea leaves & 161 & $93.8 \pm 3.64 \mathrm{aA}$ & $92.9 \pm 4.05 \mathrm{aA}$ & $92.9 \pm 4.05 \mathrm{aA}$ \\
\hline Annona neolaurifolia leaves & 137 & $93.2 \pm 1.04 \mathrm{aA}$ & $93.2 \pm 1.04 \mathrm{aA}$ & $93.2 \pm 1.04 \mathrm{aA}$ \\
\hline Annona neolaurifolia stem bark & 160 & $94.2 \pm 2.60 \mathrm{aA}$ & $94.2 \pm 2.60 \mathrm{aA}$ & $93.6 \pm 2.18 \mathrm{aA}$ \\
\hline Annona sylvatica leaves & 123 & $89.7 \pm 4.78 \mathrm{aA}$ & $89.7 \pm 4.78 \mathrm{aA}$ & $87.4 \pm 4.39 \mathrm{aA}$ \\
\hline Duguetia lanceolata stem bark & 142 & $68.4 \pm 6.24 \mathrm{bA}$ & $62.6 \pm 8.19 \mathrm{cA}$ & $59.0 \pm 7.43 \mathrm{cA}$ \\
\hline Duguetia lanceolata leaves & 121 & $91.0 \pm 1.90 \mathrm{aA}$ & $90.0 \pm 1.68 \mathrm{aA}$ & $88.8 \pm 1.84 \mathrm{aA}$ \\
\hline Duguetia lanceolata berry fruits & 170 & $93.3 \pm 0.82 \mathrm{aA}$ & $93.3 \pm 0.82 \mathrm{aA}$ & $92.1 \pm 0.87 \mathrm{aA}$ \\
\hline Guatteria australis leaves & 143 & $93.5 \pm 2.56 \mathrm{aA}$ & $88.9 \pm 5.16 \mathrm{aA}$ & $88.9 \pm 5.16 \mathrm{aA}$ \\
\hline Xylopia brasiliensis leaves & 166 & $96.8 \pm 1.24 \mathrm{aA}$ & $96.8 \pm 1.24 \mathrm{aA}$ & $96.8 \pm 1.24 \mathrm{aA}$ \\
\hline Xylopia emarginata stem bark & 181 & $95.2 \pm 2.82 \mathrm{aA}$ & $95.2 \pm 2.82 \mathrm{aA}$ & $95.2 \pm 2.82 \mathrm{aA}$ \\
\hline Xylopia emarginata leaves & 146 & $90.0 \pm 2.96 \mathrm{aA}$ & $90.0 \pm 2.96 \mathrm{aA}$ & $88.4 \pm 4.52 \mathrm{aA}$ \\
\hline Xylopia sericea stem bark & 178 & $95.8 \pm 2.38 \mathrm{aA}$ & $95.8 \pm 2.38 \mathrm{aA}$ & $94.4 \pm 1.94 \mathrm{aA}$ \\
\hline Xylopia sericea leaves & 177 & $94.6 \pm 3.59 \mathrm{aA}$ & $93.6 \pm 3.20 \mathrm{aA}$ & $93.6 \pm 3.20 \mathrm{aA}$ \\
\hline Xylopia sericea berry fruits & 105 & $84.3 \pm 4.67 \mathrm{aA}$ & $78.5 \pm 8.29 \mathrm{bA}$ & $76.7 \pm 8.42 \mathrm{bA}$ \\
\hline Dicofol at $0.01\left(\mathrm{v} \cdot \mathrm{v}^{-1}\right)$ & 113 & $0.0 \pm 0.00 \mathrm{cA}$ & $0.0 \pm 0.00 \mathrm{dA}$ & $0.0 \pm 0.00 \mathrm{dA}$ \\
\hline
\end{tabular}

${ }^{1}$ Number of treated females; ${ }^{2}$ Values with the same letters, uppercase in rows and lowercase in columns, do not differ according to the Scott-Knott test $(\mathrm{P} \leq 0.01)$. Coefficient of variation $(\mathrm{CV}): 8.29 \%$.

Similarly, no previous reports of acaricidal activity were found for $A$. coriacea, $A$. neolaurifolia, and $A$. sylvatica, despite reports in the literature on the extraction of substances from these plants that may have potential uses as pesticides. For example, acetogenin and gigantetronenin were isolated from A. coriacea roots (SILVA et al., 1996), and these compounds inhibit the mitochondrial complex I (ÁLVAREZ-COLOM et al., 2009). The soluble methanol and hexane extracts from $A$. coriacea seeds are also known to have high insecticidal activities (COSTA et al., 2013). The differences between the results obtained in this study and those reported in the literature may be due to the use of different methodologies to obtain the metabolites.

No previous reports on acaricide activity were found for $A$. neolaurifolia and A. sylvatica. However, phytochemical studies have indicated that these species produce substances that may have pesticidal activity (NASCIMENTO et al., 2003; PIMENTA et al., 2005; FORMAGIO et al., 2013). Acetylcholinesterase inhibitory activity has been reported for the alcoholic extract from the branches of $G$. australis, while the same bioactivity was not observed for the leaf extract (CARDOSO-LOPES et al., 2008). This last result is consistent with the inactivity of the G. australis leaf fraction observed in the present study.

For the species from the Xylopia genus, just a fraction from $X$. sericea fruit caused a reduction in $T$. tumidus. Previous studies on the essential oils from leaves and fruits of this plant have demonstrated that they have an acaricidal effect on T. urticae (PONTES et al., 2007). No previous reports of acaricide activity were found for $X$. brasiliensis and $X$. emarginata. However, phytochemical studies have indicated that metabolites from these plants may have toxic effects on herbivores (LAGO et al., 2003, 2005; MOREIRA et al., 2013). 
Effect of the dichloromethane soluble fraction from D. lanceolata stem bark on T. tumidus eggs

There was no reduction in the number of hatched nymphs, compared to the negative controls ( $F$ $=17.14 ; \mathrm{df}=3 ; \mathrm{p} \leq 0.01)$, when $T$. tumidus eggs were treated with the $D$. lanceolata stem bark fraction (Table 3). This may be because the egg stage is the most resistant to adverse environmental conditions in many groups of arthropods. Therefore, natural plant products are generally more toxic to larval and adult stages of Tetranychus spp. (CHANDRASHEKHARAIAH et al., 2011; ERDOGAN et al., 2012).

Table 3. Numbers of hatched Tetranychus tumidus nymphs (\%) (mean \pm SE) after egg treatment with the dichloromethane soluble fraction from Duguetia lanceolata stem bark.

\begin{tabular}{lcc}
\hline Treatment & $\mathbf{n}^{\mathbf{1}}$ & Nymphs hatched $\mathbf{( \% )} \pm \mathbf{S E}^{\mathbf{2}}$ \\
\hline Water & 408 & $82.9 \pm 9.21 \mathrm{a}$ \\
DMSO $\left(0.05 \mathrm{v} \cdot \mathrm{v}^{-1}\right)+$ Tween $80\left(0.01 \mathrm{v} \cdot \mathrm{v}^{-1}\right)$ & 385 & $77.6 \pm 11.93 \mathrm{a}$ \\
Duguetia lanceolata stem bark & 432 & $71.7 \pm 9.34 \mathrm{a}$ \\
Dicofol $^{\circledR}$ & 298 & $0.0 \pm 0.00 \mathrm{~b}$ \\
\hline
\end{tabular}

${ }^{1}$ Total number of eggs; ${ }^{2}$ Values with the same letters do not differ according to the Scott-Knott test $(\mathrm{P} \leq 0.01)$. Coefficient of variation $(\mathrm{CV}): 46.48 \%$.

Effect of the $\underline{D}$. lanceolata stem bark fraction on $\underline{T}$. urticae adult females

The $D$. lanceolata stem bark fraction was most active against $T$. tumidus, so the fractions from the plant tissues of this plant were selected for the $T$. urticae bioassay. It was found that the leaf, berry fruit, and stem bark fractions reduced $T$. urticae survival $(F=648.78 ; \mathrm{df}=5 ; \mathrm{p} \leq 0.01)$. Survival was not affected over the period of exposure to treatments $(\mathrm{F}=1.256 ; \mathrm{df}=2 ; \mathrm{p}=0.28)$. However, the best results were found when the D. lanceolata stem bark fraction was applied which, $72 \mathrm{~h}$ after the start of the bioassay, caused $95.5 \%$ mortality, a value statistically equal to that observed for the positive control, dicofol (Table 4). The D. lanceolata stem bark fraction was more active against $T$. urticae than $T$. tumidus, which must be a result of speciesspecific variations. It is relatively common that related species of arthropods have different abilities and mechanisms for detoxifying toxic metabolites (KIM et al., 2003; SONG et al., 2011).

Table 4. Survival (\%) (mean \pm SEM) of Tetranychus urticae females subjected to treatment with soluble dichloromethane fractions from Annonaceae methanolic extracts, using an adapted micro-immersion bioassay technique, after 24,48 and $72 \mathrm{~h}$.

\begin{tabular}{|c|c|c|c|c|}
\hline Treatment & $\mathrm{n}^{1}$ & $24 h^{2}$ & $48 h^{2}$ & $72 \mathrm{~h}^{2}$ \\
\hline Water & 193 & $90.4 \pm 1.89 \mathrm{aA}$ & $88.3 \pm 1.84 \mathrm{aA}$ & $87.6 \pm 1.81 \mathrm{aA}$ \\
\hline DMSO + Tween & 269 & $89.9 \pm 0.99 \mathrm{aA}$ & $86.8 \pm 1.83 \mathrm{aA}$ & $85.3 \pm 1.99 \mathrm{aA}$ \\
\hline Duguetia lanceolata leaves & 233 & $83.4 \pm 2.69 \mathrm{bA}$ & $81.1 \pm 3.62 \mathrm{bA}$ & $80.6 \pm 3.49 \mathrm{bA}$ \\
\hline Duguetia lanceolata berry fruits & 257 & $77.5 \pm 3.64 \mathrm{bA}$ & $75.7 \pm 2.67 \mathrm{bA}$ & $74.3 \pm 2.67 \mathrm{bA}$ \\
\hline Duguetia lanceolata stem barks & 243 & $5.9 \pm 4.39 \mathrm{cA}$ & $4.5 \pm 4.28 \mathrm{cA}$ & $4.5 \pm 4.28 \mathrm{cA}$ \\
\hline Dicofol & 257 & $0.0 \pm 0.00 \mathrm{cA}$ & $0.0 \pm 0.00 \mathrm{cA}$ & $0.0 \pm 0.00 \mathrm{cA}$ \\
\hline
\end{tabular}

${ }^{1}$ Total number of eggs; ${ }^{2}$ Values with the same letters, uppercase in rows and lowercase in columns, do not differ according to the Scott-Knott test $(\mathrm{P} \leq 0.01)$. Coefficient of variation $(\mathrm{CV}): 14.62 \%$. 
Analysis by GC-MS

The constituent analysis of the $D$. lanceolata stem bark fraction revealed the presence of two major constituents. The first peak showed a retention time (RT) of $4.28 \mathrm{~min}$, and the highest mass/charge value $(\mathrm{m} / \mathrm{z})$ was equal to $194 \mathrm{u}$, which possibly corresponded to the molecular ion peak $[\mathrm{M}]^{+}$. Studies previously performed by our research group (ALVES, 2014), and comparison with the literature data (Table 5), suggested that this substance was 2,4,5-trimethoxystyrene $(\mathrm{RT}=$ $4.28 \mathrm{~min}$ ) (Figure 1). The other substance had a RT equal to 5.74 minutes, and the highest $\mathrm{m} / \mathrm{z}$ value was 209 , which probably corresponded to $[\mathrm{M}]^{+}$. A comparison of its mass spectra with mass spectra in the NIST library 08 suggested that this compound was the phenylpropanoid compound, trans-asarone (Figure 1), with similarity rates equal to $96 \%$. This result was corroborated by comparison of the mass spectra obtained in this study with those described in the literature for this substance (Table 5).

Table 5. Mass/charge $(\mathrm{m} / \mathrm{z})$ ratio for the peaks observed in the mass spectra of the major compounds (2,4,5-trimethoxystyrene and trans-asarone) in the chromatogram of the Duguetia lanceolata stem bark fraction. The analyses were performed by mass spectrometry coupled to gas chromatography.

\begin{tabular}{|c|c|c|c|c|c|c|c|c|c|}
\hline \multicolumn{4}{|c|}{ 2,4,5-trimethoxystyrene } & \multicolumn{6}{|c|}{ trans-asarone } \\
\hline $\mathrm{m} / \mathrm{z}^{1}$ & $\mathrm{IR}^{1,2}$ & $(\mathrm{~m} / \mathrm{z})^{3}$ & $\mathrm{IR}^{2,3}$ & $\mathrm{~m} / \mathrm{z}^{1}$ & $\mathrm{IR}^{1,2}$ & $(\mathrm{~m} / \mathrm{z})^{4}$ & $\mathrm{IR}^{2,4}$ & $(\mathrm{~m} / \mathrm{z})^{5}$ & $\mathrm{IR}^{2,5}$ \\
\hline 194 & 100 & 194 & 100 & 208 & 100 & 208 & 100 & 208 & 100 \\
\hline 179 & 71 & 179 & 61 & 193 & 47 & 193 & 45 & 193 & 38 \\
\hline 151 & 65 & 151 & 46 & 177 & 6 & 177 & 4 & 177 & 4 \\
\hline 136 & 23 & 136 & 13 & 165 & 33 & 165 & 25 & 165 & 23 \\
\hline 121 & 11 & 121 & 7 & 162 & 14 & 162 & 13 & - & - \\
\hline 108 & 11 & - & - & 150 & 11 & 150 & 9 & 150 & 8 \\
\hline 91 & 28 & 91 & 11 & 137 & 22 & 137 & 9 & 137 & 8 \\
\hline 77 & 22 & - & - & 118 & 5 & - & - & - & - \\
\hline 69 & 17 & 69 & 11 & - & - & 119 & 9 & - & - \\
\hline 65 & 14 & - & - & 105 & 14 & 105 & 8 & 105 & 4 \\
\hline 51 & 11 & 51 & 8 & 91 & 17 & 91 & 11 & 91 & 8 \\
\hline \multirow[t]{5}{*}{-} & - & 39 & 4 & 79 & 14 & - & - & 79 & 4 \\
\hline & & & & - & - & 77 & 8 & - & - \\
\hline & & & & 69 & 14 & 69 & 13 & 69 & 8 \\
\hline & & & & 65 & 8 & - & - & - & - \\
\hline & & & & 51 & 3 & - & - & - & - \\
\hline
\end{tabular}

${ }^{1}$ Experimental value; the substances were ionized by electron impact at $70 \mathrm{eV} ;{ }^{2} \mathrm{RPI}=$ relative peak intensity; ${ }^{3} \mathrm{Nagashima}$ et al. (1999); ${ }^{4}$ Oprean et al. (1998); ${ }^{5} \mathrm{Zuo}$ et al. (2012).

Trans-asarone and 2,4,5-trimethoxystyrene are relatively common metabolites in the Annonaceae family (WANG et al., 1988; NGADJUI et al., 1989; SILVA et al., 2007; YAPI et al., 2012). It is noteworthy that trans-asarone was recently identified as a component of an essential oil extracted from D. lanceolata branches (SOUSA et al., 2012).
Moreover, the abundance of 2,4,5-trimethoxystyrene and trans-asarone in the D. lanceolata stem bark, as shown by the GC-MS analysis (Figure 1), is consistent with the high activity against $T$. urticae, since both molecules are known to have insecticidal activity (KOONA; BOUDA, 2006; BHARDWAJ et al., 2010). It is noteworthy that the acaricidal 
activity of these molecules is supported by the fact that other molecules, also belonging to the phenylpropanoids chemical class, have also been reported to have acaricidal activity. In particular, the phenylpropanoid, eugenol, is known to have activity against $T$. urticae, and some researchers have attributed its mechanism of action and toxicity to fumigant contact (HAN et al., 2011; ARAÚJO et al., 2012).

Figure 1. Chromatogram of the dichloromethane soluble fraction from the methanolic extract of Duguetia lanceolata stem barks, which was obtained by gas chromatography coupled to mass spectrometry. The main substances, identified as 2,4,5-trimethoxystyrene (1) and trans-asarone (2), were ionized by electron impact at $70 \mathrm{eV}$.

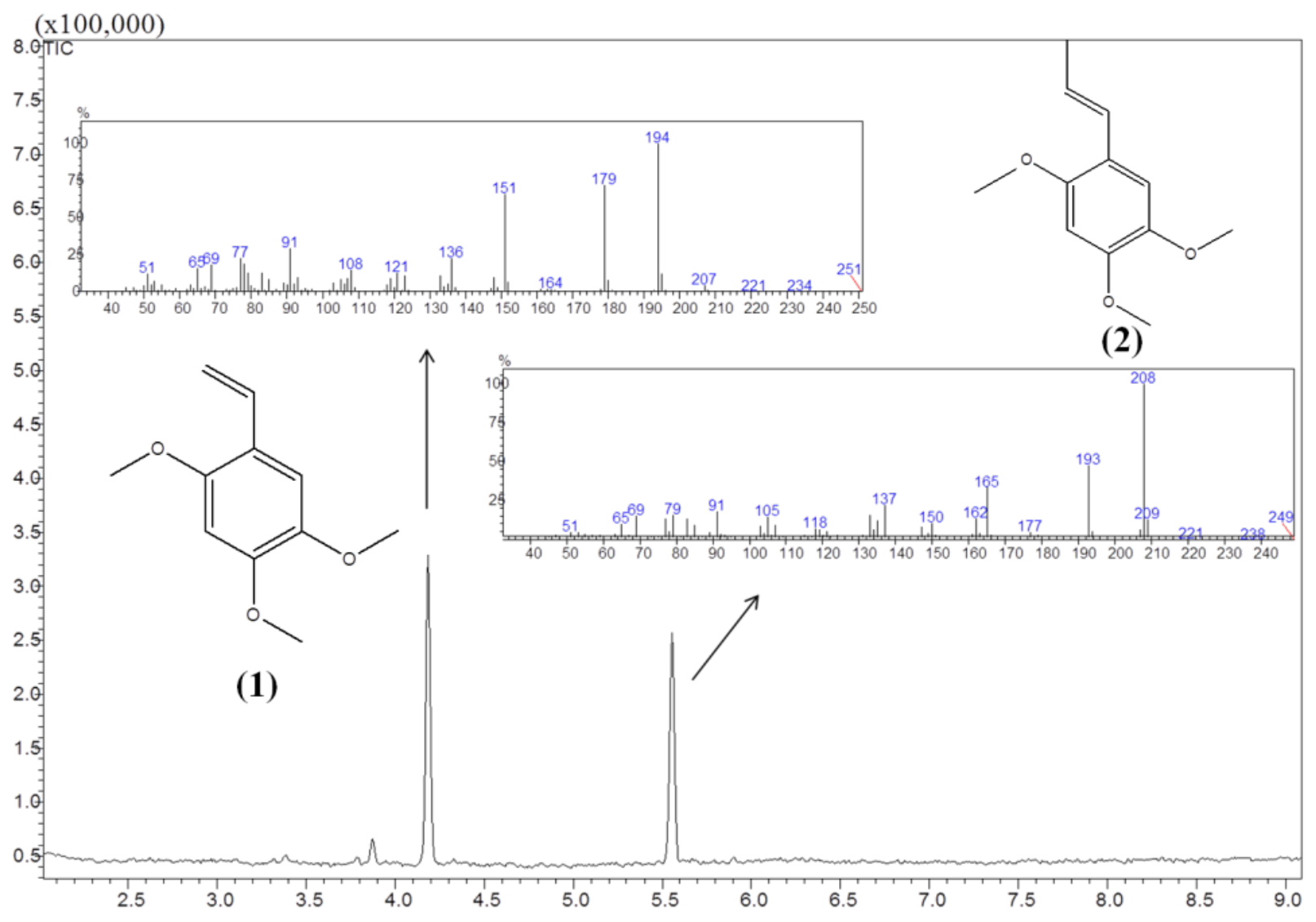

\section{Conclusions}

The fraction from $D$. lanceolata stem barks reduced T. tumidus and T. urticae survival. The highest mortality rate was observed for T. urticae. According to the GC-MS analysis, the major constituents of the dichloromethane soluble fraction in the extract from $D$. lanceolata were 2,4,5-trimethoxystyrene and trans-asarone, of which there are no previous reports regarding their pesticide activity. Therefore, the results of this study show that $D$. lanceolata stem bark could potentially be used to develop new products for the control of T. urticae and T. tumidus.

\section{Acknowledgements}

The authors acknowledge financial support from FAPEMIG, CNPq, and CAPES. They thank Prof ${ }^{a}$ Dra Vanda Helena Paes Bueno and Dr ${ }^{\text {a }}$ Maria de los Angeles Martínez Rivero, the coordinators of the 
cooperation project: CAPES BRASIL/MES CUBA, for their assistance.

\section{References}

AKENDENGUE, B.; NGOU-MILAMA, E.; BOUROBOU-BOUROBOU, H.; ESSOUMA, J.; ROBLOT, F.; GLEYE, C.; LAURENS, A.; HOCQUEMILLER, R.; LOISEAU, P.; BORIES, C. Acaricidal activity of Uvaria versicolor and Uvaria klaineana (Annonaceae). Phytotherapy Research, London, v. 17, n. 4, p. 364- 367, 2003.

ÁlVAREZ-COLOM, O.; BARRACHINA, I.; MINGOL, I. A.; MAS, M. C. G.; SANZ, P. M.; NESKE, A.; BARDON, A. Toxic effects of annonaceous acetogenins on Oncopeltus fasciatus. Journal of Pest Science, New York, v. 81, n. 2, p. 85-89, 2008.

ÁlVAREZ-COLOM, O.; NESKE, A.; CHAHBOUNE, N.; ZAFRA-POLO, M. C.; BARDÓN, A. Tucupentol, a novel mono-tetrahydrofuranic acetogenin from Annona montana, as a potent inhibitor of mitochondrial complex I. Chemistry \& Biodiversity, Weinheim, v. 6, n. 3, p. 335340, 2009.

ÁlVAREZ-COLOM, O.; NESKE, A.; POPICH, S.; BARDÓN, A. Toxic effects of annonaceous acetogenins from Annona cherimolia (Magnoliales: Annonaceae) on Spodoptera frugiperda (Lepidoptera: Noctuidae). Journal of Pest Science, New York, v. 80, n. 1, p. 63-67, 2007.

ALVES, D. S. Prospecção de metabólicos de anonáceas ativos para Spodoptera frugiperda e Tetranychus_spp. 2014. Tese (Doutorado em Agronomia/Entomologia) Universidade Federal de Lavras, Lavras.

ARAÚJO, M. J. C.; CÂMARA, C. A. G.; BORN, F. S.; MORAES, M. M.; BADJI, C. A. Acaricidal activity and repellency of essential oil from Piper aduncum and its components against Tetranychus urticae. Experimental and Applied Acarology, Amsterdam, v. 57, n. 2, p. 139155, 2012.

ATTIA, S.; GRISSA, K. L.; GHRABI,Z.G.; MAILLEUX, A. C.; LOGNAY, G.; HANCE, T. Acaricidal activity of 31 essential oils extracted from plants collected in Tunisia. Journal of Essential Oil Research, Carol Stream, v. 24, n. 3, p. 279-288, 2012.

BHARDWAJ, A.; TEWARY, D. K.; KUMAR, R.; KUMAR, V.; SINHA, A. K.; SHANKER, A. Larvicidal and structure-activity studies of natural phenylpropanoids and their semisynthetic derivatives against the tobacco armyworm Spodoptera litura (Fab.) (Lepidoptera: Noctuidae). Chemistry \& Biodiversity, Weinheim, v. 7, n. 1, p. 168-177, 2010.
CARDOSO-LOPES, E. M.; CARREIRA, R. C.; AGRIPINO, D. G.; TORRES, L. M. B.; CORDEIRO, I.; BOLZANI, V. D. S.; DIETRICH, S. M. D. C.; YOUNG, M. C. M. Screening for antifungal, DNA-damaging and anticholinesterasic activities of Brazilian plants from the Atlantic Rainforest - Ilha do Cardoso State Park. Brazilian Journal of Pharmacognosy, João Pessoa, v. 18, p. 655-660, 2008. Supplement.

C H A N D R A S H E K H A R A I A H ; SANNAVEERAPPANAVAR, V. T.; PRASHANT; SATHISH; NAVEENA, N. L. Evaluation of acaricidal properties of selected plant extracts and organic materials against two spotted spider mite, Tetranychus urticae Koch (Tetranychidae: Acari). Biopesticides International, Jalandhar, v. 7, n. 1, p. 35-42, 2011.

COSTA, M. S.; PEREIRA, M. J. B.; OLIVEIRA, S. S.; SOUZA, P. T.; DALL'OGLIO, E. L.; ALVES, T. C. Anonáceas provocam mortalidade em larvas de Aedes aegypti (Linnaeus, 1762) (Diptera: Culicidae). Revista Brasileira de Biociências, Porto Alegre, v. 11, n. 2, p. 184-190, 2013.

DENNEHY, T.; FARNHAM, A.; DENHOLM, I. The microimmersion bioassay: a novel method for the topical application of pesticides to spider mites. Pesticide Science, Oxford, v. 39, n. 1, p. 47-54, 1993.

DING, L. J.; DING, W.; ZHANG, Y. Q.; LUO, J. X. Bioguided fractionation and isolation of esculentoside P from Phytolacca americana L. Industrial Crops and Products, New York, v. 44, p. 534-541, 2013.

ERDOGAN, P.; YILDIRIM, A.; SEVER, B. Investigations on the effects of five different plant extracts on the two-spotted mite Tetranychus urticae Koch (Arachnida: Tetranychidae). Psyche: Journal of Entomology, Cambridge, v. 2012, art. $\mathrm{n}^{\circ} .125284$, p. 1-5, 2012.

FISCHER, D. C.H.; GUALDA, N. C. D. A.; BACHIEGA, D.; CARVALHO, C. S.; LUPO, F. N.; BONOTTO, S. V.; ALVES, M. D. O.; YOGI, A.; SANTI, S. M. D.; AVILA, P. E.; KIRCHGATTER, K; MORENO, P. R. H. In vitro screening for antiplasmodial activity of isoquinoline alkaloids from Brazilian plant species. Acta Tropica, Basel, v. 92, n. 3, p. 261-266, 2004.

FORMAGIO, A. S. N.; VIEIRA, M. D. C.; DOS SANTOS, L. A. C.; CARDOSO, C. A. L.; FOGLIO, M. A.; CARVALHO, J. E. de; ANDRADE-SILVA, M.; KASSUYA, C. A. L. Composition and evaluation of the anti-inflammatory and anticancer activities of the essential oil from Annona sylvatica A. St. -Hil. Journal of Medicinal Food, Florida, v. 16, n. 1, p. 20-25, 2013. 
GHADERI, S.; MINAEI, K.; ROWSHAN, V.; GHAMADYARI, M. Toxicity and ovicidal activity of different plant extracts on two-spotted spider mite, Tetranychus urticae Koch (Acari: Tetranychidae). Archives of Phytopathology and Plant Protection, London, v. 46, n. 1, p. 120-126, 2013.

GUPTA, A.; PANDEY, S.; SHAH, D. R.; YADAV, J. S.; SETH, N. R. Annonaceous acetogenins: the unrevealed area for cytotoxic and pesticidal activities. Systematic Reviews in Pharmacy, Mumbai, v. 2, n. 2, p. 104-109, 2011.

HAN, J.; KIM, S. I.; CHOI, B. R.; LEE, S. G.; AHN, Y. J. Fumigant toxicity of lemon eucalyptus oil constituents to acaricide-susceptible and acaricide-resistant Tetranychus urticae. Pest Management Science, Sussex, v. 67, n. 12, p. 1583-1588, 2011.

JAREK, S. R Package: mvnormtest: normality test for multivariate variables. 2009. Available at: $<$ http://cran.rproject.org/web/packages/mvnormtest/index $>$. Accessed at: 10 dec. 2013.

KIM, E. H.; KIM, H. K.; AHN, Y. J. Acaricidal activity of clove bud oil compounds against Dermatophagoides farinae and Dermatophagoides pteronyssinus (Acari: Pyrogiyphidae). Journal of Agricultural and Food Chemistry, Easton, v. 51, n. 4, p. 885-889, 2003.

KOONA, P.; BOUDA, H. Biological Activity of Pachypodanthium staudtii (Annonaceae) against the bean beetle Acanthoscelides obtectus Say (Coleoptera: Bruchidae). Journal of Applied Sciences Research, Faisalabad, v. 2, n. 12, p. 1129-1131, 2006.

LABORDA, R.; MANZANO, I.; GAMÓN, M.; GAVIDIA, I.; PÉREZ-BERMÚDEZ, P.; BOLUDA, R. Effects of Rosmarinus officinalis and Salvia officinalis essential oils on Tetranychus urticae Koch (Acari: Tetranychidae). Industrial Crops and Products, New York, v. 48, p. 106-110, 2013.

LAGO, J. H. G.; MOREIRA, I. C.; TANIZAKI, T. M.; MORENO, P. R. H.; ROQUE, N. F.; LIMBERGER, R. P.; APEL, M. A.; HENRIQUES, A. T. Mono and sesquiterpenes from the leaf essential oil of Xylopia brasiliensis Spreng. (Annonaceae). Journal of Essential Oil Research, Carol Stream, v. 15, n. 6, p. 406-407, 2003.

LAGO, J. H. G.; REIS, A. A.; MARTINS, D.; CRUZ, F. G.; ROQUE, N. F. Composition of the leaf oil of Xylopia emarginata Mart. (Annonaceae). Journal of Essential Oil Research, Carol Stream, v. 17, n. 6, p. 622-623, 2005.

LEEUWEN, T. V.; VONTAS, J.; TSAGKARAKOU, A.; DERMAUW, W.; TIRRY, L. Acaricide resistance mechanisms in the two-spotted spider mite Tetranychus urticae and other important Acari: A review. Insect
Biochemistry and Molecular Biology, Oxford, v. 40, n. 8, p. 563-572, 2010.

LIN, C. Y.; WU, D. C.; YU, J. Z.; CHEN, B. H.; WANG, C. L.; KO, W. H. Control of silverleaf whitefly, cotton aphid and kanzawa spider mite with oil and extracts from seeds of sugar apple. Neotropical Entomology, Londrina, v. 38, n. 4, p. 531-536, 2009.

LÜMMEN, P. Complex I inhibitors as insecticides and acaricides. Biochimica et Biophysica Acta-Bioenergetics, Amsterdam, v. 1364, n. 2, p. 287-296, 1998.

MADHUMITHA, G.; RAJAKUMAR, G.; ROOPAN, S. M.; RAHUMAN, A. A.; PRIYA, K. M.; SARAL, A. M.; KHAN, F. R. N.; KHANNA, V. G.; VELAYUTHAM, K.; JAYASEELAN, C.; KAMARAJ, C.; ELANGO, G. Acaricidal, insecticidal, and larvicidal efficacy of fruit peel aqueous extract of Annona squamosa and its compounds against blood-feeding parasites. Parasitology Research, Berlin, v. 111, n. 5, p. 2189-2199, 2012.

MARCIC, D. Acaricides in modern management of plant-feeding mites. Journal of Pest Science, New York, v. 85, n. 4, p. 395-408, 2012.

MCLAUGHLIN, J. L. Paw paw and cancer: Annonaceous acetogenins from discovery to commercial products. Journal of Natural Products, Cincinnati, v. 71, n. 7, p. 1311-1321, 2008.

MOREIRA, I. C.; ROQUE, N. F.; VILEGAS, W.; ZALEWSKI, C. A.; LAGO, J. H. G.; FUNASAKI, M. Genus Xylopia (Annonaceae): Chemical and biological aspects. Chemistry \& Biodiversity, Weinheim, v. 10, n. 11, p. 1921-1943, 2013.

NAGASHIMA, F.; MURAKAMI, Y.; ASAKAWA, Y. Aromatic compounds from the Ecuadorian liverwort Marchesinia brachiata: a revision. Phytochemistry, New York, v. 51, n. 8, p. 1101-1104, 1999.

NASCIMENTO, F. D. C. do; DIAMANTINO BOAVENTURA, M. A.; ASSUNÇÃO, A. C. S.; SANTOS PIMENTA, L. P. Acetogeninas de anonáceas isoladas de folhas de Rollinia laurifolia. Química Nova, São Paulo, v. 26, n. 3, p. 319-322, 2003.

NEVES, I. A.; DA CAMARA, C. A. G. Acaricidal activity against Tetranychus urticae and essential oil composition of four croton species from caatinga biome in northeastern Brazil. Natural Product Communications, Ohio, v. 6, n. 6, p. 893-899, 2011.

NGADJUI, B. T.; LONTSI, D.; AYAFOR, J. F.; SONDENGAM, B. L. Pachypophyllin and pachypostaudins A and B: three bisnorlignans from Pachypodanthium staudtii. Phytochemistry: Chemistry, Biochemistry, Molecular Biology, New York, v. 28, n. 1, p. 231-234, 1989. 
OLIVEIRA-FILHO, A. T. TreeAtlan 2. 0, flora arbórea da América do Sul cisandina tropical e subtropical: um banco de dados envolvendo biogeografia, diversidade e conservação. Belo Horizonte: Universidade Federal de Minas Gerais, 2010. Disponível em: <http://www.icb. ufmg.br/treeatlan/>. Acesso em: 20 nov. 2013.

OPREAN, R.; TAMAS, M.; ROMAN, L. Comparison of GC-MS and TLC techniques for asarone isomers determination. Journal of Pharmaceutical and Biomedical Analysis, Londres, v. 18, n. 1-2, p. 227-234, 1998.

PIMENTA, L. P. S.; NASCIMENTO, F. C.; BOAVENTURA, M. A. D. Acetogenins from the leaves of Rollinia laurifolia. Helvetica Chimica Acta, Basel, v. 88, n. 12, p. 3225-3231, 2005.

PONTES, W. J. T.; OLIVEIRA, J. C. S.; CÂMARA, C. A. G.; GONDIM JÚNIOR, M. G. C.; OLIVEIRA, J. V.; SCHWARTZ, M. O. E. Atividade acaricida dos óleos essencias de folhas e frutos de Xylopia sericea sobre o ácaro rajado (Tetranychus urticae Koch). Química Nova, São Paulo, v. 30, n. 4, p. 838-841, 2007.

POTENZA, M. R.; GOMES, R. C. O.; JOCYS, T.; TAKEMATSU, A. P.; RAMOS, A. C. O. Avaliação de produtos naturais para o controle do ácaro rajado Tetranychus urticae (Koch, 1836) (Acari:Tetranychidae) em casa de vegetação. Arquivos do Instituto Biológico, São Paulo, v. 73, n. 4, p. 455-459, 2006.

R DEVELOPMENT CORE TEAM. R: a language and environment for statistical computing. Vienna: Editora, 2013. Available at: $<$ http://www.R-project.org $>$. Accessed at: 1 jul. 2013.

SAITO, M. L; ALVARENGA, M. A. Composiçäo química de Annona cacans Warming. Lecta-USF, Bragança Paulista, v. 12, n. 1, p. 135-140, 1994.

SATO, M. E.; SILVA, M. Z.; RAGA, A.; SOUZA FILHO, M. F. Abamectin resistance in Tetranychus urticae Koch (Acari: Tetranychidae): selection, cross-resistance and stability of resistance. Neotropical Entomology, Londrina, v. 34, n. 6, p. 991-998, 2005.

SILVA, D. B. da; TULLI, E. C. O; GARCEZ, W. S.; NASCIMENTO, E. A.; DE SIQUEIRA, J. M. Chemical constituents of the underground stem bark of Duguetia furfuracea (Annonaceae). Journal of the Brazilian Chemical Society, São Paulo, v. 18, n. 8, p. 1560-1565, 2007.

SILVA, E. L. M. da; ROBLOT, F.; MAHUTEAU, J.; CAVÉ, A. Coriadienin, the first annonaceous acetogenin with two double bonds isolated from Annona coriaceae. Journal of Natural Products, Cincinnati, v. 59, n. 5, p. 528-530, 1996.
SILVA, L. J. da. $R$ package: DUNCAN test, Tukey test and Scott-Knott test. [S.1.: s.n.], 2010. Available at: $<$ http://cran.r-project.org/web/packages/laercio/laercio. pdf>. Accessed at: 10 dez. 2013.

SOKOLYANSKAYA, M. P. The problem of the insect and mite resistance to insectoacaricides; resistance to organochlorines and organophosphates. Resistant Pest Management Newsletter, East Lensing, v. 19, n. 2, p. 6266, 2010.

SOMKUWAR, D. O.; KAMBLE, V. A. Phytochemical screening of ethanolic extracts of stem, leaves, flower and seed kernel of Mangifera indica L. International Journal of Pharma and Bio Sciences, New Delhi, v. 4, n. 2, p. 383-389, 2013.

SONG, H. Y.; YANG, J. Y.; SUH, J. W.; LEE, H. S. Acaricidal activities of apiol and its derivatives from petroselinum sativum seeds against Dermatophagoides pteronyssinus, Dermatophagoides farinae, and Tyrophagus putrescentiae. Journal of Agricultural and Food Chemistry, Easton, v. 59, n. 14, p. 7759-7764, 2011.

SOUSA, O. V.; DEL-VECHIO-VIEIRA, G.; ALVES, M. S.; ARAÚJO, A. A. L.; PINTO, M. A. O.; AMARAL, M. P. H.; RODARTE, M. P.; KAPLAN, M. A. C. Chemical composition and biological activities of the essential oils from Duguetia lanceolata St. Hil. Barks. Molecules, Switzerland, v. 17, n. 9, p. 11056-11066, 2012.

TEMPONE, A. G.; TREIGER BORBOREMA, S. E.; ANDRADE JÚNIOR, H. F. de; AMORIM GUALDA, N. C. de; YOGI, Á.; SALERNO CARVALHO, C.; BACHIEGA, D.; LUPO, F. N.; BONOTTO, S. V.; FISCHER, D. C. H. Antiprotozoal activity of Brazilian plant extracts from isoquinoline alkaloid-producing families. Phytomedicine: International Journal of Phytotherapy and Phytopharmacology, Jena, v. 12, n. 5, p. 382-390, 2005.

UDDIN, M. R.; LI, X.; KIM, Y. B.; CHAE, S. C.; KIM, S. -J.; PARK, S. U. Phenolic compounds in different organs of tartary buckwheat (Fagopyrum tataricum Gaertn.) cultivars. Australian Journal of Crop Science, Lismore, v. 7, n. 12, p. 1861-1865, 2013.

VALENTE, P. P.; AMORIM, J. M.; CASTILHO, R. O.; LEITE, R. C.; RIBEIRO, M. F. B. In vitro acaricidal efficacy of plant extracts from Brazilian flora and isolated substances against Rhipicephalus microplus (Acari: Ixodidae). Parasitology Research, Berlin, v. 113, n. 1, p. 417-423, 2014.

VERONEZ, B.; SATO, M. E.; NICASTRO, R. L. Toxicidade de compostos sintéticos e naturais sobre Tetranychus urticae e o predador Phytoseiulus macropilis. Pesquisa Agropecuária Brasileira, Brasília, v. 47, n. 4, p. 511-518, 2012. 
WANG, Z. W.; MA, W. W.; MCLAUGHLIN, J. L.; GUPTA, M. P. 2,4,5- trimethoxystyrene, a bioactive component of the bark of Duguetia panamensis. Journal of Natural Products, Cincinnati, v. 51, n. 2, p. 382-384, 1988.

YANAR, D.; KADIOĞLU, D.; GÖKÇE, A. Ovicidal activity of different plant extracts on twospotted spider mite (Tetranychus urticae Koch) (Acari: Tetranychidae). Scientific Research and Essays, Lagos, v. 6, n. 14, p. 3041-3044, 2011.

YAPI, T. A.; BOTI, J. B.; FÉLIX, T. Z.; AHIBO, A. C.; TOMI, F.; BIGHELLI, A. Pachypodanthium staudtii Engl \& Diels from côte d'ivoire: composition of leaf, stem bark and roots oils. European Journal of Scientific Research, Victoria, v. 69, n. 1, p. 137-142, 2012.
ZHANG, Q.; DING, L.; LI, M.; CUI, W.; DING, W.; LUO, J.; ZHANG, Y. Action modes of Aloe vera L. extracts against Tetranychus cinnabarinus Boisduval (Acarina: Tetranychidae). Agricultural Sciences, Mississippi, v. 4, n. 3, p. 117-122, 2013.

ZUO, H. L.; YANG, F. Q.; ZHANG, X. M.; XIA, Z. N. Separation of cis and trans-asarone from Acorus tatarinowii by preparative gas chromatography. Journal of Analytical Methods in Chemistry, New York, v. 2012, p. 1-5, 2, Art. ID 402081, 2012. 